\title{
IRANIAN ELITES' CULTURAL HEGEMONY DURING THE SELJUK AND ITS INFLUENCE ON THE ART OF METALWORKING
}

\author{
Mehran Golestan \\ $\mathrm{PhD}$ student .University of Art. Tehran .Iran \\ golestan_mehran@yahoo.com \\ S.Saeed S.A.Zavieh \\ Associate Professor .University of Art .Tehran. Iran \\ zavieh@art.ac.ir \\ Mohsen Rahmani \\ MA Illustration .Shahed University. Tehran. Iran \\ a2nias@yahoo.com
}

\begin{abstract}
Iran has an ancient and influential history among the Middle East countries, so the review of Seljuk history in Iran may create new perspective into this era in terms of study nature. In addition,several researches have been published in the field of Seljuk's art history in Iran and Rome. In this paper, seeking for a fundamental goal, we aimed to consider a different approach to study the metal works remained from Seljuk era in Iran during $11^{\text {th }}$ and $12^{\text {th }}$ century AD by going through systematic literature review and library documents, in particular literature pertaining to the sociological concepts like Antonio Gramsci's idea about, with the aim of achieving the impact of the presence of society's political and cultural eliteson the creation of these works. Finally, the most important result obtained by studying and observing the most outstanding metal works of Seljuk era is the cultural hegemony of elites. As it was expected in the magnificent era of Seljuk Kings, Iranshahr thought, which was inspired by Ancient Iran in the words of ministers and scholars invited to the court as cultural and political elites, directly affected the beliefs and behavior pattern of the society and subsequently the favor of artists and then overshadowed the creation of artistic works, and the present article is intended to explain it.
\end{abstract}

Keywords: Iran's art, Seljuks in Iran, cultural hegemony, Iranshahr thought, Aristocracy, metal works

\section{INTRODUCTION}

Traditional arts and crafts of Iran, as one of the most important and magnificent fields of Islamic Arts, is a medium through which the ancient culture of Iran is linked to the contemporary art. In this while, Iran, the Seljuk's art might be a sign of a nation's efforts to preserve the legacy of the ancients, to the extent that the artists of that era not only trying to regenerate old traditions of art, but also get help of their innovation and creativity to revive Iranian culture; it leads to maintain and introduce one of the significant Persian arts, i.e. metalworking as the most popular cultural identity of the Seljuk era.

Investigation and study about the art of Seljuk era indicates the complexity and multi-aspect of the art in Seljuk era. Investigation of metalworking art of Seljuk from historical and analytical perspective in the previous literature indicates the necessity to complete artistic studies by adopting different approaches and using various methods such as sociological approach which is the viewpoint of this article, because adopting every kind of approach and attitude toward one of art's aspects will form a certain type of associated method.

The purpose of this article is to analyze artistic products (censer) of Seljuk era to specify that how much the prevalent hegemony of that era has dominated the space of Arts and Culture? Therefore, researchers have used arts sociology to validate the content.

Submit Date: 21.06.2016, Acceptance Date: 26.07.2016, DOI NO: 10.7456/1060AGSE/039 


\section{STATEMENT OF THE PROBLEM}

Undoubtedly, extensive historical studies and descriptive approaches have been considered by the researchers to investigate Arts and Cultural works in different historical periods and many articles have been published in this particular field. Although this type of studies are essential and successful in their place, they are incomplete because do not consider causal relationships and are not able to explain all the aspects of art sociology, especially the viewpoint taken in this article, that is the hegemony of elites.

Therefore, the second form of the study which is causal investigation is free of this deficiency. Causal investigation means that the researcher, as Max Weber says, does not start from the point that the arts are existed, but first he asks that why and how the arts are created? This question which can be solved by investigation and analysis of sociological approaches has not been studied by the researchesas it should be.

The importance of such questions is proposed in the theory of intellectuals like "Antonio Gramsci", "Arnold Hauser" and "Karl Mannheim" and they have said to understand a work of art, it is sufficient to refer to the social and economic conditions in whichthe creator of the work had been, especially to his social class, and then to know him; in this case we can understand his work as well. According to Karl Mannheim, artistic styles emerged throughout history represent and reflect the desires of groups and classes that create them, means that he considers the forms directly related to social structures such as social groups and classes.

Hauser also believes that art is more influenced by social factors rather than any other cultural structures, although this effect is hidden but it exists.

Accordingly, the role of Seljuk Turks in Iran's Art history is organized in a way that most historians and artists consider their government as the bloom of Islamic art in Iran during the past fourteen centuries. Although the domain of Seljuk empire encompasses from China to Andalusia, they have not considerable art due to the nomadic life; but after coming to power and expanding their empire from Central Asia to Egypt,a scientific-artistic rebirth and renaissance in the Islamic world, especially Iran, was occurred. At this time,academic, cultural and political situation of Iran paved the way for scientific, cultural and artistic development and growth by the emergence of prominent figures such as Nezam al-Molk, Hakim Omar Khayam, Khaghani, Nizami Ganjavi, Mohammad Hassan Sabbah, Naser Khosro Qobadyani, and ImamMohammad Ghazali and ... as cultural elites.

The cultural space during Seljuk era had caused the Kings and rich men to financiallysupport and sponsorthe artists and craftsmen. Although these extensive supports were owing to the political purposes, it led to the emergence of a special style and procedure in arts and crafts (from Khorasan to Mousel), which was later calledas "Seljuk school" by the scholars of Islamic art. Seljuk Schoolin their empire domain was manifested with distinctive features compared withthe periods before and after in most of artistic fields.

\section{THEORETICAL FRAMEWORK}

It should be pointed that artistic creation is a part of social realities, taking a new form by the evolutions in social periods proportional to the social needs, and then come to existence from inside the life current. Accordingly, we can agree with György Lukács and Lucien Goldman believing that, art works of each erais influenced by the social and economic conditions of that time. In other words, socioeconomic conditions of the artists or his social class determines his choice of style and content, but is have to be considered that this relationship is not direct and is established by the worldview and ideology.

"Andre Godard" the French orientalist and scholar of Iranian studies says that: "art is primarily the reflection of the artist's spirit and the abstract of forces that leading him ... and the important principle in art and architecture of a nation is the community spirit of them". 
"Antonio Gramsci", Italian sociologist, believes that civil society is the requirement of hegemony, and put it against the oppressive government. He means hegemony to exercise cultural leadership and mastery from the ruling class. Gramsci's emphasis on cultural leadership and mastery has two meanings. First,the supremacy related to the process inside the civil society thereby a single class exercises his intellectual and moral mastery on other classes. Second,supremacy refers to the relationship between dominant classes and dominated classes. Here, supremacy is the successful efforts of the dominant class to use their power for controlling social resources. In his view, the ruling classhas acknowledged a supremacy (or dominant influence) that convince other classes to accept their values, ethics and ideas in the most natural way. He sees art products as a hegemonic tool serving for the ruling class, to establish a consensus on power. When we compare the concept of hegemony and ideology, we see that ideology is inherently static, whereas hegemony has dynamic nature.

From Antonio Gramsci's perspective, hegemony means to produce cultural consensus and satisfaction. On the other words, hegemony means a kind of self-fabricated and self-motivated satisfaction. On the contrary to the ideology that is from top down, forceful with deception and cheating, hegemony would be intertwined with all the aspects of human lives such that takes the form of common sense. Ideology has got a political aspect, while hegemony has cultural one. On the other hand, according to the concept of ideology by Althusser, there is no possibility of resistance and struggle, but Gramsci argues that hegemony is a combination of domination and resistance.

Hegemony refers to a situation in which a temporary coalition of social groups can lead to the social authority on other subordinate groups. This authority is not exercised only through the use of force or direct imposition of governor's ideas, but also by satisfying and shaping it, so that the power of the dominant classes would be appeared to be both legitimate and natural. Hegemony can only be maintained when the dominant classes are successful to shape all the competing definitions in the framework of their desire; means that they should always try to show it permanent and normal.

Gramsci added that the hegemonic power can never be permanently exercised by the alliance of "parts of the dominant class" precisely because it requires the consent of the dominated majority. In the other words, hegemony is not universal and not delegated to the permanent and continuing government of a particular class. Hegemony must be provided, reproduced, and maintained. As Gramsci said, hegemony is a Moving Equilibrium that include the relationships of favorable or unfavorable forces, on this or that tendency.

Maintaining and continuing the hegemony by the society requires the dominant groups to support their functional groups by privileges such as wages, facilities, services, etc. Therefore, there is a high degree of consensus and social stabilityin a hegemonic society, and the dominated classes support the values and ideas given by the dominant class and link them to the power structure in the society.

From the standpoint of cultural theories, culture has not a constant existence and is affected by current struggles and debates. Therefore, mass culture is the area of collision between dominant and dominated forces in society. Means that, there is a dialectic between the dominance field and resistance field in the culture. Thus, according to the theory of hegemony, cultural products, unlike the Frankfurt School, are not single, sealed, and imposed and not considered solely as a tool of domination, but rather a mix of top to bottom, forced, spontaneous, hegemonic and resistive cultural flows.

\section{METALWORKING ART, THE MANIFESTATION OF SELJUK THOUGHT AND CULTURE CONQUEST}

On the basis of what was said and the theory of Hegemony, the question that comes to mind is that, can Seljuk metal works be considered as a mixture of top-down cultural flows or elite hegemony? If yes, based on what evidences we can prove the hypothesis that metal works are bedrock of elite hegemony. 
For this purpose, we should note consider two notes: first, metalworking in Seljuk era covered the aspects of Islamic art by preserving the grandeur, splendor and elegance of ancient Sassanid period. The encouragement and supports of Seljuk for excellence in the art were also effective in a way that many artistic developments emerged in the fields of architecture, metalwork, ceramics, glass, textiles, and son by the appearance of this school, which was especially flourished in Khorasan and Isfahannomads. Many arts were complemented compare to the previous periods and innovations were achieved in most arts and crafts that absorbed the consideration of artists and craftsmen all around the world.

Second, metalworking art of Iranian Seljuk is one of the most brilliant traditional arts in Iran after Islam, and the artists in the eleventh and twelfth centuries have produced the best metal work in all areas including the necessities of life such as dishes, bowls, and cups, ewer, candlestick etc.

Additionally, metalworking art of Iran is the reflection of a society produced it. Life styles, mental concerns, desires and ideals of the supporters and Kings are all expressed through the performance and value of the things used by them. Metalworking as an art-craft has traditionally achieved an important place among other art crafts. Iran's metalworking art reflects national moods and emotions in different period of times and has been together with Iranian people's fortune during all the events, even the conquest of aliens. About the year $1037 \mathrm{AD}$, by the arrival of the Seljuks in eastern Iran, Islamic metalwork brilliant period began.

Important governmental centers of Seljuk in this era were Marv, Nishabour, Rey, Isfahan and other cities such as Hamadan, Sistan, Herat and Mosul that most of these areas have been considered as important metalworking centers.

In this era, metalworking and manufacturing metal products reached to the highest quality, popularity and prosperity and Khorasan province has been a pioneer in this field. Perhaps, the reason for the primacy of this city is that, during the Samanid Empire (819-999 AD), Khorasan was the largest center of production and manufacture of Bronze utensils and their design in accordance with the graphic styles of Ancient Iran or Sassanid Style. (Figure 2) Just because of some additions and nuances in the works, experts can find out the nature and time of production.

Also, given the penchant of the rulers in Mazandaran region along Caspian Sea during Buyid dynasty (934-1062Mylady) to their historical background, they protected the utensils remained from Sassanid Empire metal in their homes, and metalwork artists of this region emulated these works. Therefore, most of metal dishes of Iran are obtained from this region.

Metal objects of Buyid dynasty include medals with the pictures and sculptures made of gold and silver with the Iranian Prince's name; and as mentioned, there are objects at the interface between Sassanid metal objects showing Islamic spirit and concepts (Figure 3). Although courtier scenes, such as celebrations, ceremonies, hunting, fetes and music in this era was different from Sassanid art in terms of clothing from, but the contents of Sassanid dynasty are observed in some detail. Thus, Buyid era is considered as the brilliant ages of the metalworking industry.

In the review of arts in Abbasids Caliphate era, it has been said that the artists of this period of Islamic art believe that the use of precious metals such as gold and silver is forbidden; so the best metalworking was performed with bronze in Khorasan and West Turkestan. But Buyid artists not only ignored Abbasid beliefs, but also started to compete with the metalworkers of Sassanid dynasty in Iran. In this while, numerous gold and silver plates, gold cups and also medals decorated with carvings of the princes were made. It was thought in the past that, the silverware of this period should be referred to Sassanid era, because the dishes portrayed the art of Sassanid craftsmen. However, a detailed survey on the methods observed in previous work determined that these objects were made during Buyid dynasty. 
"Katly" and "Hamby", in the book "Safavid and Khwarizmi about the art of metalworking" wrote: "metalworking in Seljuk period was of especial prosperity and development, this technique was always on a high level of construction quality and established unique artistic goals. These goals were almost met because numerous metal dishes, especially those made in Khorasan, had the date, signature, and signs of adept founder, gravure makers, and practitioners". In support of this statement, Mohammad Hassan wrote: "metalworking industry Seljuk era, and flourished through the Seljuk lands that were outstanding in this area, this province is located in the front line. Maybe it's the province Samanid empire era (261389 E. 847-999M) center of a large and utensils made of bronze and decorated with ancient map of the Sasanian style. "(MH, 1377, 25)

Therefore, it can be supposed that Islamic metalworking in Iran follows the art of Sassanid era, with a difference that craftsmen started to make dishes and objects from other metals and alloys such as bronze and iron due to the inhibition of using precious metals in the production of applied dishes and objects. Changes in the religious beliefs and the materials led to the development of this art in accordance with society's beliefs and customs, especially in the eastern Iranian tribes.

Most of metal products and variety of works during Seljuk era in Islamic states including Iran were made of copper and its alloys such as bronze and brass. Most of them were also patchworked with precious metals like gold and silver, and efforts were undertaken to decorate them as possible. Many of these products are not intended for daily use, but also have been prepared for officials and wealthy people with decorative and ceremonial application.

Lukac believes that, there are some artworks in a particular society which reasonably similar despite apparent differences, and containing the same attitudes about life, death and the supernatural world. The most important of these artworks in fact act as a filter conveys the common idea of that era.Lukacconsiders the idea of single-worldview as a factor that enables us to put an artwork in its existential and everyday human perspective.

Therefore, an artwork can be understood in the context of social conditions it has been created; and the characteristic of these social conditions is its dominant worldview. Thus, a metalwork master who had made metalwork has been in a society and a social group, in more details. This society and social group had got a certain and specific worldview, and he had adopted this worldview following to its social group, then reflected its concepts and illustrative essence in his work of art. It should be noted that this process takes place unconsciously, not in a way that artist adopt a worldview consciously and tries to illustrate it in his work. As "Goldman"says: the more is the cohesion of an artist to the social group, and the wider is his social eyesight, he can better convey his desired worldview (either unconsciously or consciously).

Accordingly, it can be said that Seljuk metal works in Iran reflect the social conditions of archaism thought reproduction age leading to the expansion of making such works combined with the picture of mythic animals in Ancient Iran. Although this reflection is not direct and acting through worldviews and ideologies which is affiliated to the class system of that time. In the above example, ministers and thinkers of Seljuk dynasty convey the worldview in archaism thought.

Lucian Goldman believes that everybody is member of social groups and this membership is reflected in his thinking, emotions and behavior. The relationships between humans and the relationship between human and environment in the larger social groups are reorganized so that the social structure would be survived. Awareness, feelings and behavior of the members of these larger social groups are inspired by this reorganizing.Goldman interprets this kind of comprehensive relationships as "worldview". According to his interpretation, worldviews are originated from social groups and developed in them. Thus, in the given period of time, Seljuk bureaucrats turned into a worldview called Iranshahr thought.

Regarding to the explanation of social causality of art by the means of worldview, Goldman also believes that the characteristic of cultural works is that in which the person wants to achieve a correlated world 
consistent with a certain worldview. The problems is that it is not possible for all the people to achieve such a correlation, unless partially and approximately. The question arises here is that how we can achieve such a correlated world in Seljuk era? The answer might be that, creative writers have contributed to this collective self-consciousness by describing and introducing this worldview. It can be found by taking a look on the books published in this era on the basis of Ancient Iran ideas that, to what extent the attention of artists and authors have been drawn to this worldview either unconsciously or consciously. For example, according to what is in the history books, the Seljuk was the first government in the Islamic era that could extend the boundaries of its territory as that of Sassanid era, in the West. These victories and extension of territory and authority achieved by the Seljuk Kings had to be combined with political legitimacy. Perhaps, it is why the role of Iranian Ministers was thereafter more manifested in terms of linking the power of Seljuk King with power levers of Sassanid era. Means the same correlated world considered by Goldman which can bring many people together based on a worldview. But on which part of the governmental structure this worldview crystallized itself? Perhaps the answer lied in the history of domination of various tribes and rulers over geographic area of Iran.

An overview on the governance of Seljuk before entering Iran shows that they ruled based on tribalism and were dependent on Iranian bureaucracy to administer their territory. Actually, it was Iranian bureaucrats who assisted them to continue their government and authority using Iranian-Islamic tradition. The Seljuk were initially aware of their weaknesses to administer regions like Khorasan. The Seljuk Toqrol said to Qazi Saed at the triumph of Nishabour City that: "'we are new and alien people who do not know Iranian customs". Therefore, they resorted to the assistance and tact of Iranian bureaucrats in political, social and cultural decisions to compensate for this weakness, as with most of Iran's conquerors. It should be noted the Seljuk bureaucracy rooted in the beforehand traditions. A root which can be called "Iranshahrthought".

\section{IRANSHAHR THOUGHT, THE MANIFESTATION OF IRANIAN ARISTOCRACY:}

A glimpse on the history of Iran in early centuries and prior to the emergence of Seljuk in Iran shows that the extension of territory and geographical dispersion of Islamic lands caused different ministries and seigniors to be gradually formed as parallel powers along with Abbasid Caliph and then made independent and dependent governments as well as ruling dynasties such as Buyid and Ghaznavian under the titles of King and Sultan to remind the experience of pre-Islam regimes in Iran. In addition, local governments across Iran paved the way to declare their dependence on Ancient era and attribute their pedigree to the Ancient regimes. Insomuch as it has been mentioned in historical books that, many dynasties and local Amirs tended to construct self-made correlated and ideological world were eager to the attribution of Ancient backgrounds. Taherian dynasty were likely to attribute their generations to Rostam, al-Ziarto Kaveh, Buyid to Bahram Gur, Samanid to Bahram Chubinand historians have tried to attribute the pedigree of the Seljuk dynasty to the ancient Afrasiab.

The attention and consideration to ideal kingdom is well known in the opinions and ideas regarding of Seljuk minister, Nizam al-Mulk, insofar as he connects Iranian wisdom and Islamic tradition. Nizam alMulk, in his book entitled Siasat Nameh - which is a kind of guideline - hasobviously considered the King having divine curls and generalizes Iranshahr theory to some of Iranian caliphs and kings in Islamic era.

"Edward Brown," argues that a principle whereby a divine right of kings is attached to the king has no firm followers except Iranian of Sassanid era.

Seljuks also used the pre-Islam titles of Iran. In this regard, a document issued in 1062 AD from Tugrul Epistles Court mentioned him as "king" according to Sassanid kings.

Nizam al-Mulk and bureaucrats of the time, as the court ruling elites, could also resort to a kind of cultural control. In this elite hegemony, they (mostly) rule not by mere force and power, but through the guiding and the encouragement pathway. Hegemony is the projection of norms, values and worldviews 
injected by dominant elites, and therefore, elite play important role in the creation, acknowledgement and distribution of cultural products. Thus, the elites of Seljuk era could make the ideas consistent with their interests in the form of art. They provided the contexts for the emergence and appearance of Iranshahr thought as the dominant worldview among social groups including artists, bureaucrats, scholars and ... by the production or reproduction of common ideas for guiding and encouraging. A lot of books written in that period can be cited such as a Tajnameh,Tarikh al-Vozara, Shahnameh, Siasatnameh by Nizam alMulk, Tohfat al-Vozara byAbu Mansur Abdul Malik Salby, Tarikh al-Vozaraby Aboalrja' Qummi, Bayhaqi history, Tajareb al-Omam by Abu Ai Miskawayh that looking at Ancient Iran in the Islamic period.

Totally, what has been mentioned in these books include moral and social points and contain essential plans addressed to the successors for the revitalization of Sassanid traditions. Hence, its reproduction can be accounted as the conscious construction of social awareness in order to coordinate intellectual bases dominant on Iranian Seljuks.

"Janet Wolff" in the book "social production of art" book, believes as Lukács and Goldmanthat,although the work of art is not a direct reflection of collective consciousness and social conditions, but also is closely related to it.Janet Wolffstates that artwork reflects the ideology, but this ideology is expressed in artistic works and exercises its effects due to the aesthetic codes. Therefore, the values and ideas of the artist which are formed socially, are conveyed through artistic conventions. Means that, the ideology created under special social conditions in sicla classes and wants to be manifested under the conditions of making cultural works and by the means of artwork, is reconstructed owing to these artistic conventions and manifested indirectly. For example, the artist could show artistic criteria of the mentioned era in the texts of literati, in the words of bureaucrats and in a form equls to ancient era. An example is the metal works in the form of mythological winged animals, much like the examples of the Sassanian era. An example of a ring from Seljuk era is an evidence(Figure 5). In addition, metaljoss stick burners made under the inspiration of a combined animal belonging to the Sassanid era can be mentioned (Figure 6). All these samples or other remaining items such as Alp Arsalan plates (Figure 7) are examples of the artist in this cultural atmosphere emanating from elite hegemony and reproduction of the ancient thought that can be seen in the metal works of this era.

\section{CONCLUSION}

The extension of Ancient Iran's metalworking - in particular, Sassanid era either in terms of construction or from - can be pointed out by investigating and adapting the production space of metal works and cultural space of Seljuk era in Iran.Metal working in the Seljuk period reflects social conditions of the age of archaism thought reproduction. This is not directly reflected, but also seen in metal works through the elite hegemony. Investigation of the works by the scholars and bureaucrats of that time, as the community of elites and dominant class, indicates the production and reproduction of common ideas for guiding and encouraging artists to be attached to the dominant worldview or Iranshahr thought. The creation of artworks by the artists, like the literal texts remained from that time, is the result of the elites' impact acting like a bedrock for the emergence of concepts and contents confirmed by the society in the most beautiful and finest possible way within applicable, decorative or even luxury samples.

Investigation of the works remained from Seljuk era, especially available metal works, are successful to remind this historical approach and reflect the elite hegemony extended by the bureaucrats and scholars of that time. Each of these works suggests a part of social idea of its era. Finally, reading any of the visual signs, symbolic designs and historic or artistic objects discovered from the house, Bazaar, or the house of public opens a page of their own history and culture for us based on sociological and anthropological approaches, which its sample may not be found in any version or text stayed behind. 


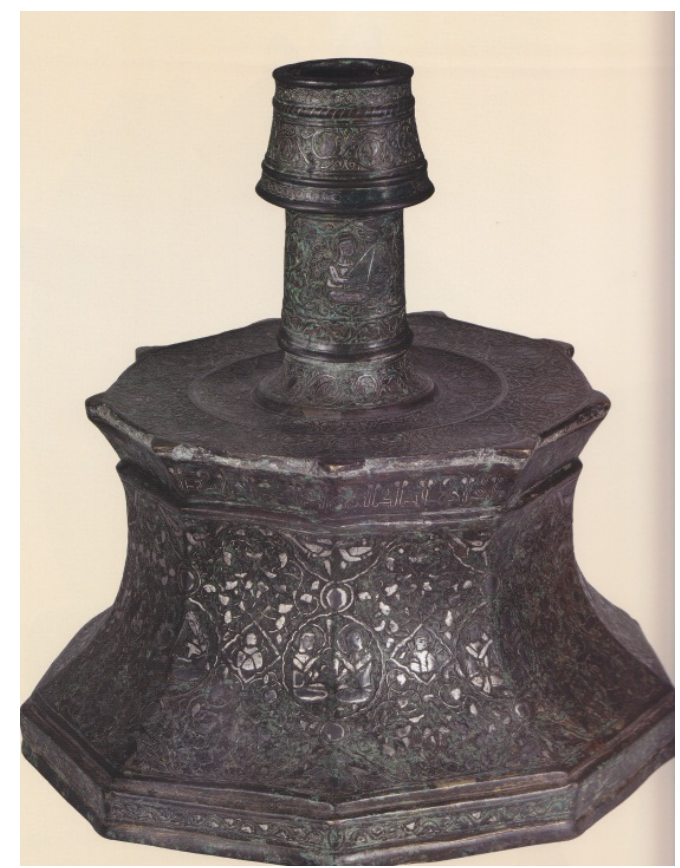

Picture1.Bronze candlesticks, silver casting, 6-7 century AH, Reza Abbasi Museum, Tehran, Iran

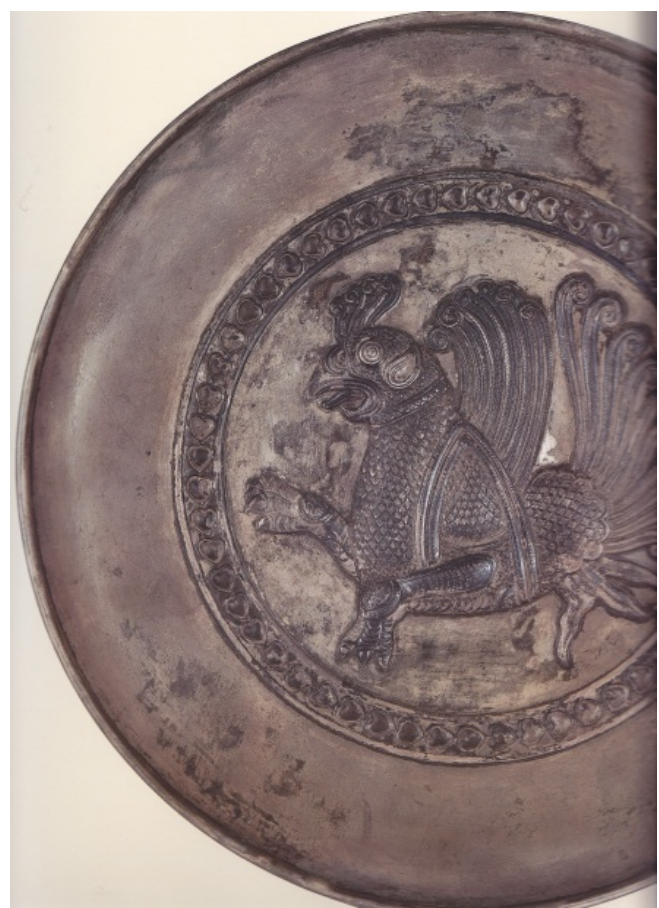

Picture2.A part of gilded silver plate, scrimshawcasting, 6-7 century AD, Reza Abbasi Museum, Tehran, Iran 


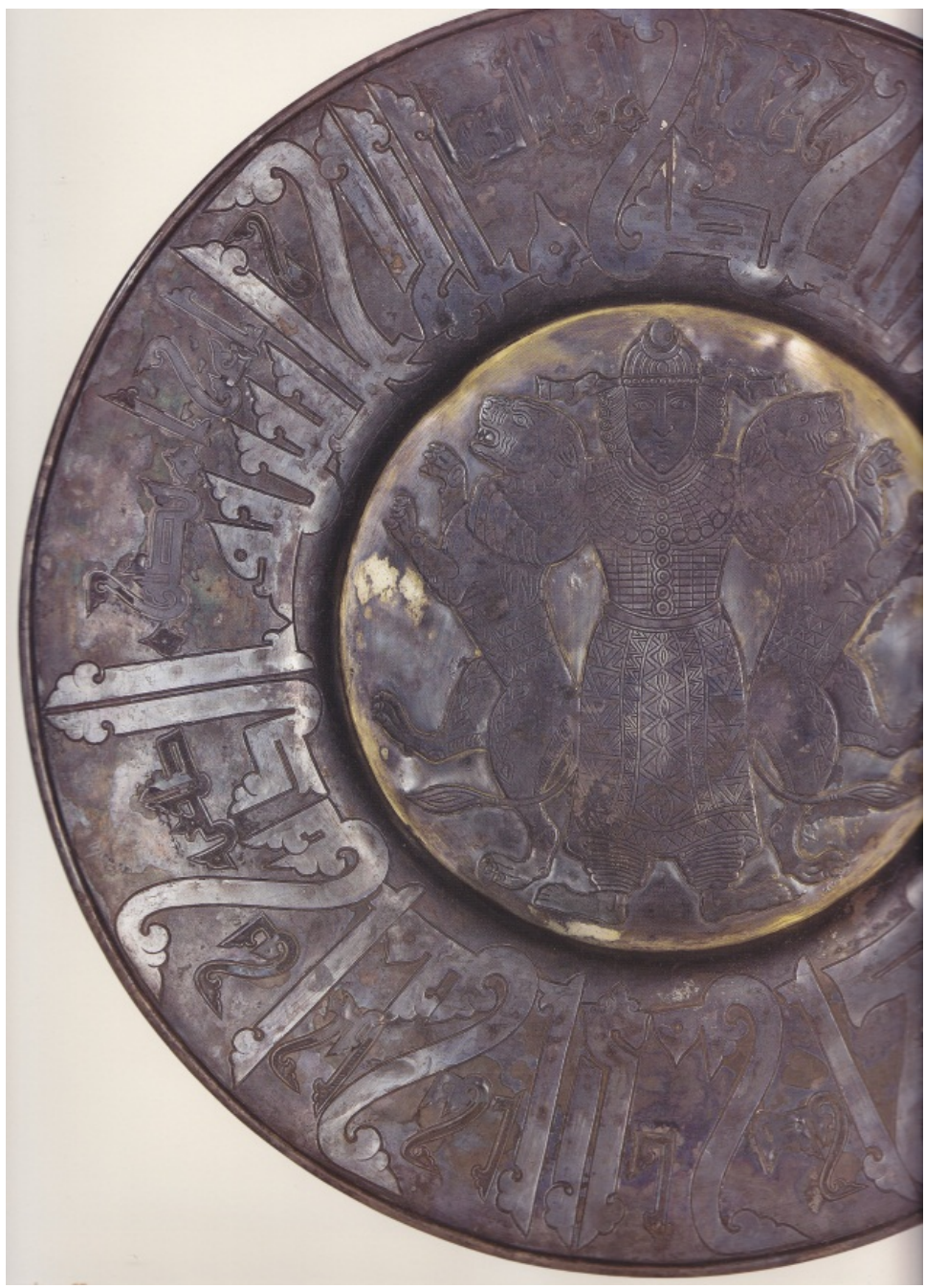

Picture3.A part of gilded silver plate, hammering and gilding, decorated with Gil Gamesh Myth with Kufic handwriting, 400 AH, Reza Abbasi Museum, Tehran, Iran 


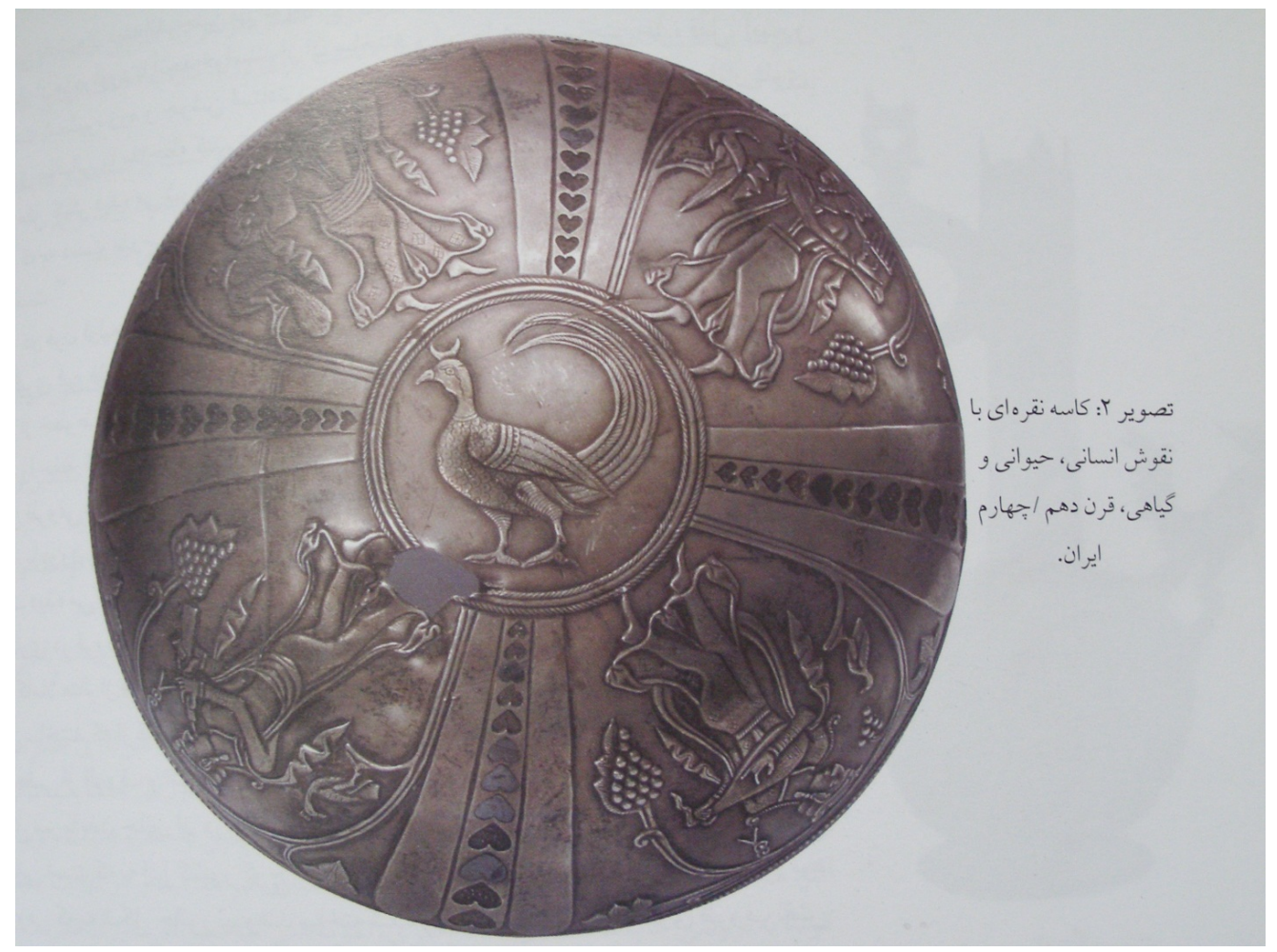

Picture4. Silver bowl with motifs of human, animal, and plant, 10 AD, Iran

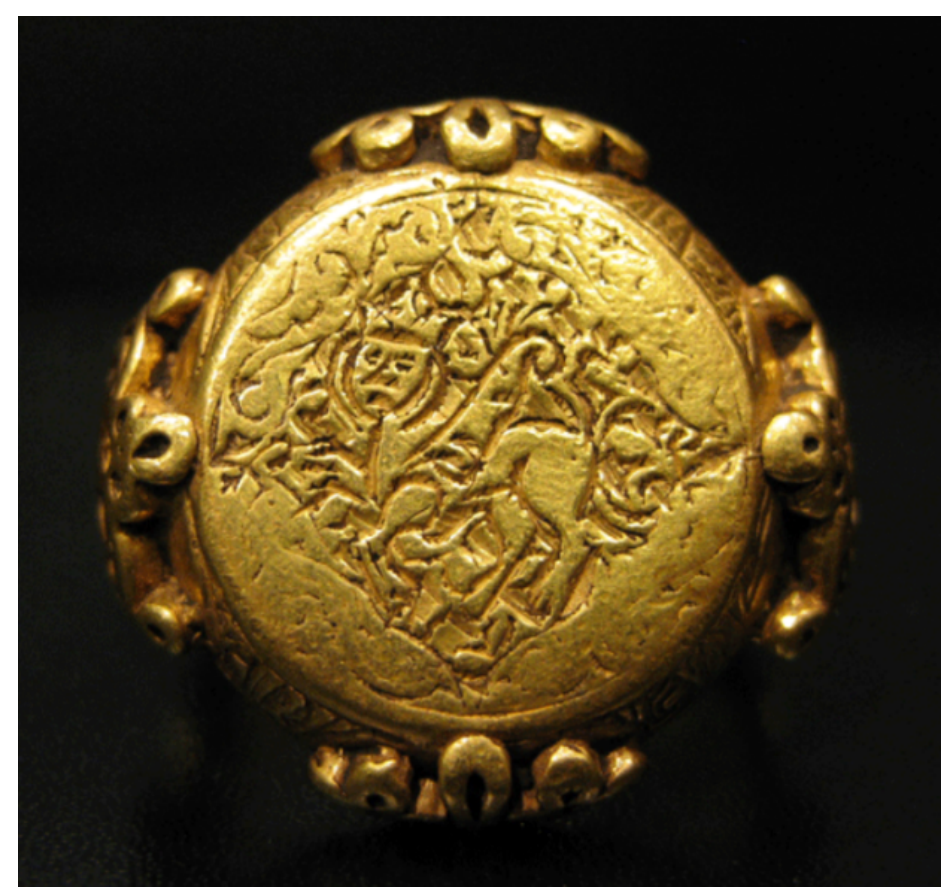

Picture5. Seal ring with the motif of winged lion inspired by mythical beliefs and legends before Islam, Metropolitan Museum, New York, America 


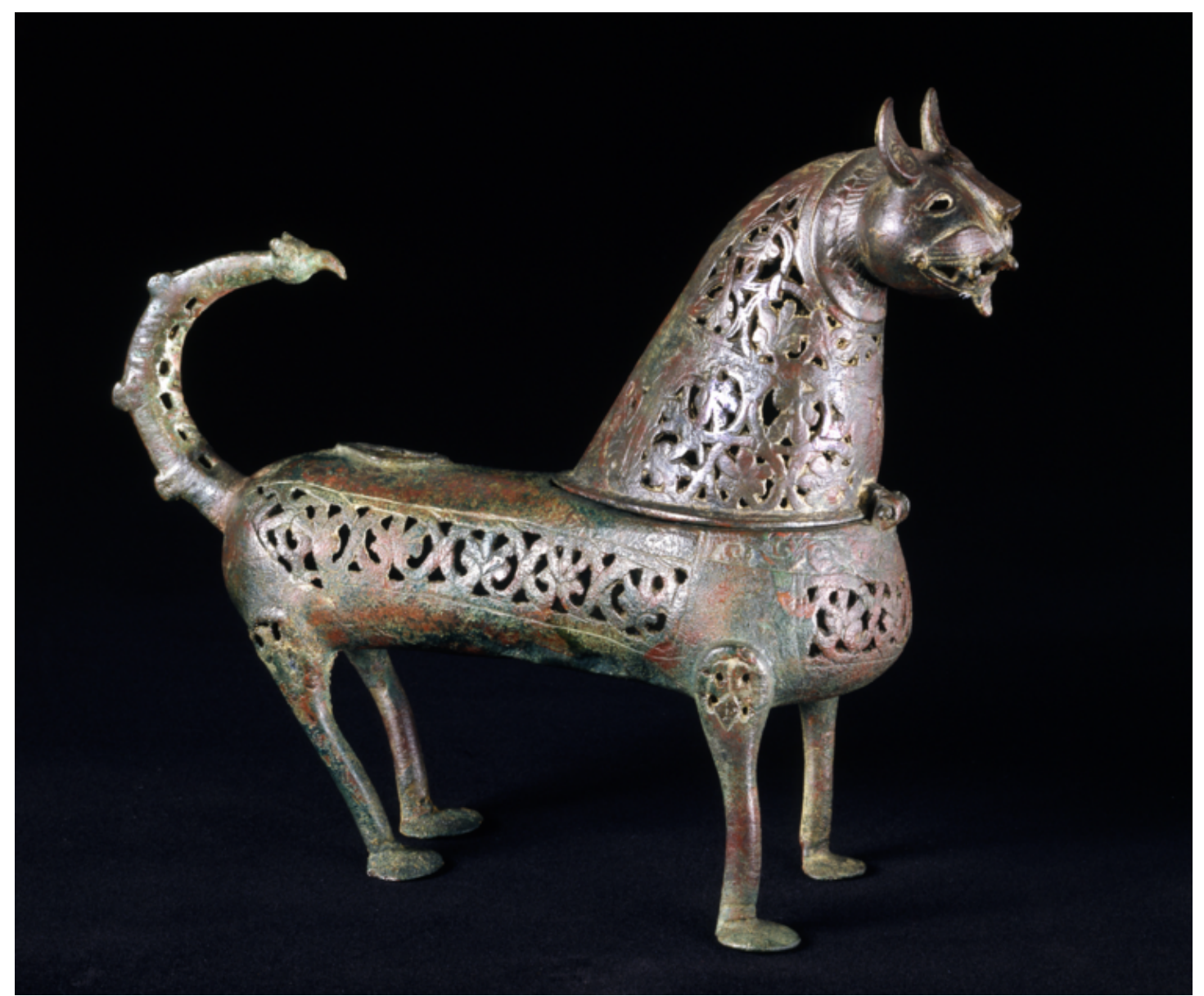

Picture6. Metal joss stick burner, with animal motifs inspired by the animal dishes of Sassanid era, Metropolitan Museum, New York, America. H: 24.5; L: $29.5 \mathrm{~cm}$ 

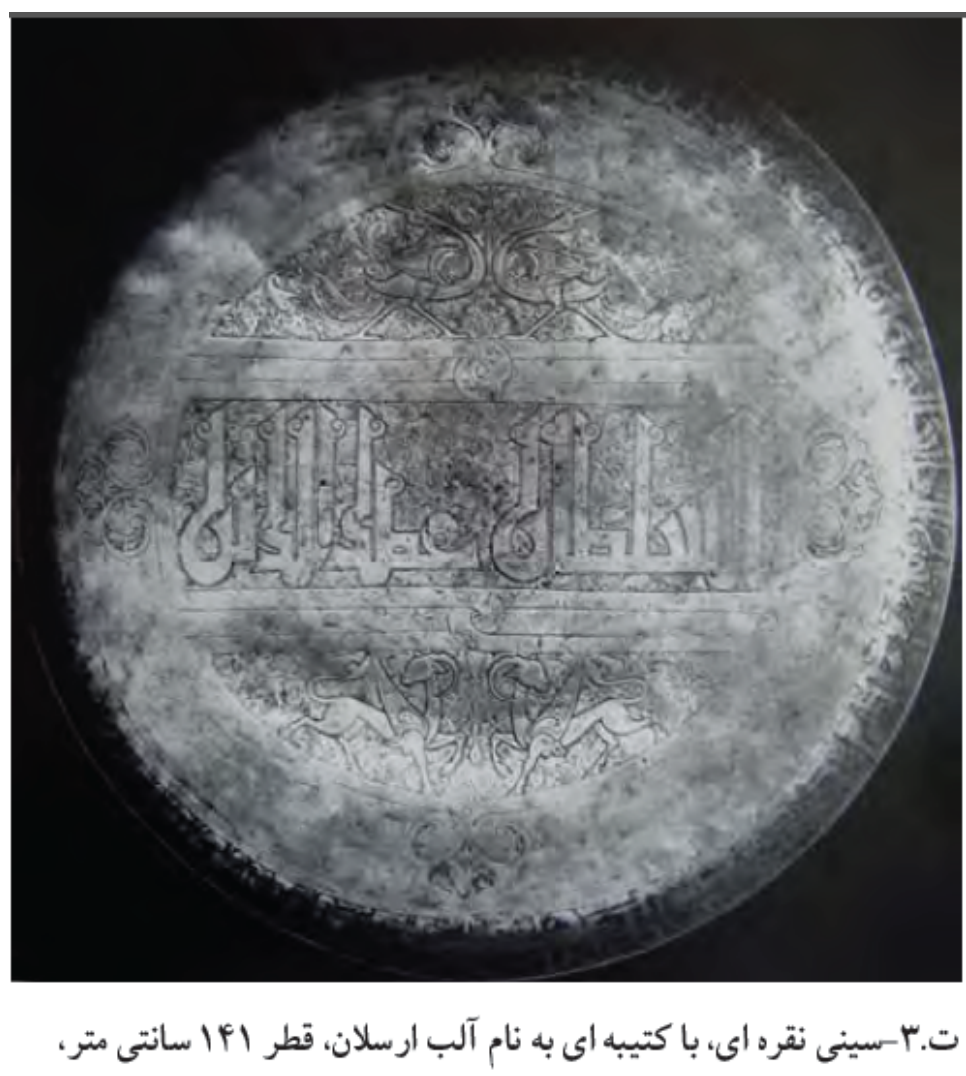

Picture7.. Alp Arsalan Silver plate, decorated with a Kufic inscription, 459 AH

\section{REFERENCES}

Asterinati, Dominique, 2001, Introduction to the Theories of Popular Culture, translated by S. Pak nazar, Tehran, Gam

Anderson, Perry,2004, equations and contradictions of Antonio Gramsci, translated by Shapur Etemad, Tehran, Tarh No

Bashiriyeh, Hossein, 2004, the history of political thoughts in the twentieth century, Tehran, Ney Nashr, Fifth Edition

Duhring Simon, 1999, cultural studies, translation by Moshirzadeh H, Tehran: Ayandeh Pooyan Institute Godard, Andre (1998), Iran's art, translation by Behrouz Habibi, Tehran, Beheshti University Press.

Hydrabadyan, Shahram (2013), Selected Works of metalworking in Reza Abbasi Museum, Tehran, Sobhan Noor

Ehsani, MohammadTaghi (1989), seven thousand years of metalworking art, Tehran, publication ...

Cavendish, Richard (2008), famous myths and religions of the world, translated by Roqiyeh Behzadi, Tehran, published by scientific publication.

Hills, John (1989) Understanding the Iranian myths, translated by Jaleh Amouzegar and Ahmad Tafazzoli, Tehran.

Ritz, George (1995), Contemporary Sociological Theories, translated by M. Salasi, Tehran: scientific publications.

Gramsci, Antonio (1983), Letters from Prison, translated by Maryam Alavi Nia, Tehran: Negah. 